Personalidade Acadêmica Homenageada:

Augustus B. Cochran III (Agnes Scott College)

\title{
ERA DA INTOLERÂNCIA DIGITAL: COMO A NÃO PERCEPÇÃO DO OUTRO AFETA A POLÍTICA BRASILEIRA
}

\section{WAS OF DIGITAL INTOLERANCE: HOW DOES NOT THE PERCEPTION OF THE OTHER AFFECT BRAZILIAN POLICY}

MATHAUS MIRANDA MACIEL

Graduando em Direito, modalidade integral, pela Escola Superior Dom Helder Câmara. Belo Horizonte-MG. E-mail: mathausmm@outlook.com

LAÍS GABRIELE PIMENTA

Graduando em Direito, modalidade integral, pela Escola Superior Dom Helder Câmara. Belo Horizonte-MG. E-mail: 99laispimenta@gmail.com

CAIO AUGUSTO SOUZA LARA Mestre e Doutor em Direito pela Faculdade de Direito da Universidade Federal de Minas Gerais - UFMG. Professor da Escola Superior Dom Helder Câmara. Pesquisador Associado ao Programa RECAJ-UFMG - Acesso à Justiça e Solução de Conflitos. Secretário de Comunicação do Conselho Nacional de Pesquisa e Pósgraduação em Direito - CONPEDI. Belo Horizonte-MG. E-mail: caiolarabh@yahoo.com.br.

\section{RESUMO}

O tema-problema da pesquisa que se pretende desenvolver é acerca das distinções, nos termos da lei, entre liberdade de expressão e discursos de ódio relacionados à política brasileira. Ademais, será abordada a influência do meio digital 


\section{Personalidade Acadêmica Homenageada:}

Augustus B. Cochran III (Agnes Scott College)

no que tange à propagação de discursos políticos intolerantes e suas implicações jurídicas, ao perceber o enfraquecimento da alteridade contemporânea. Em primeiro lugar, hoje, no país, inúmeros discursos intolerantes, com foco no sistema político brasileiro, são vistos e se utilizam do princípio da liberdade de expressão como pretexto para expressarem intolerâncias diversas. Dessa forma, quando se aborda as novas tecnologias, a situação torna-se explicita, uma vez que as redes sociais possuem relativo poder de persuasão sobre os cidadãos. Esses dispositivos, de maneira inevitável, podem ser considerados capazes de aumentar a intolerância entre os cidadãos, na medida em que é atenuado a condição de alteridade - a percepção do outro. Pode-se afirmar que, mediante os inúmeros acontecimentos de intolerância política ocorridos no país, há uma falta do sentimento de alteridade entre os indivíduos, estendendo até o ambiente virtual. Nesse âmbito, ao notar a diminuição da percepção do outro, diminui também a responsabilidade. Portanto, a alteridade é condição de possibilidade de humanização do indivíduo, uma vez que é pressuposto para uma vida em harmonia. Dessa forma, é provado que a responsabilidade, de maneira recíproca entre os indivíduos contribui para o desenvolvimento integral e integrado da sociedade. O problema objeto da investigação científica proposta é: até que ponto é dever do Estado determinar o que é liberdade de expressão e o que discurso de ódio? No âmbito político brasileiro, há o enfraquecimento da alteridade devido à expansão das redes sociais? A partir das reflexões preliminares sobre o tema, é possível afirmar inicialmente que a liberdade de expressão não se confunde com o discurso de ódio. Contudo, a livre expressão de ideias não se faz um valor incondicional, já que o direito à livre manifestação de ideias é também regulado pela Constituição. Supõe-se ainda que as redes sociais influenciam o comportamento dos indivíduos, ora atuando de maneira benéfica, ora exercendo um papel que estimula a não alteridade e propicia o aumento de discursos intolerantes, relacionados ou não à política. Ainda, é levantada a hipótese da prática do diálogo e o debate de ideias como princípio de garantia democrática, a fim de que sejam estimulados o consenso e a tolerância entre os indivíduos. O objetivo geral do trabalho é analisar até que ponto é o ordenamento jurídico pode determinar o que é liberdade de expressão e o que é discurso de ódio, de acordo com a condição da alteridade contemporânea. A pesquisa 
Personalidade Acadêmica Homenageada:

Augustus B. Cochran III (Agnes Scott College)

que se propõe pertence à vertente metodológica jurídico-sociológica. No tocante ao tipo de investigação, de acordo com Witker (1985) e Gustin (2010), o tipo jurídicoprojetivo. O raciocínio desenvolvido na pesquisa será predominantemente dialético. De acordo com a técnica de análise de conteúdo, afirma-se que se trata de uma pesquisa teórica, o que é possível a partir da análise de conteúdo dos textos, doutrinas, normas e demais dados colhidos na pesquisa. A partir do exposto, concluise preliminarmente que o tema proposto visa ao combate a discursos de ódio político presentes no país. É importante salientar que é livre o direito à livre expressão, entretanto se a intolerância for comprovada, o indivíduo é responsável pelo ato dentro dos termos da lei. Assim, a liberdade de expressão, quando não reconhecida como intolerância, é fundamental para o bem-estar da democracia, pois é considerada um direito individual, contudo de alcance coletivo e de utilização por toda a sociedade, pois é fundamental que esse direito seja resguardado pelo Estado, conforme orienta a Constituição.

PALAVRAS-CHAVE: Discurso de ódio; Liberdade de expressão; Política; Redes Sociais; Alteridade.

\section{REFERÊNCIAS}

BRASIL. Constituição da República Federativa do Brasil de 1988. Disponível em: http://www.planalto.gov.br/ccivil_03/constituicao/constituicao.htm. Acesso em: 30 abr. 2019.

CAVALCANTI, Thais Novaes; TREVISAM, Elisaide de Morais. A "Abordagem das Capacidades" na teoria de Amartya Sem sobre o desenvolvimento humano. Revista Jurídica - UNICURITIBA, Curitiba, v.1 n.54, p. 173 - 192, 2019. Disponível em: http://revista.unicuritiba.edu.br/index.php/RevJur/article/view/3305/371371798. Acesso em: 20 mai. 2019.

GUSTIN, Miracy Barbosa de Sousa; DIAS, Maria Tereza Fonseca. (Re)pensando a Pesquisa Jurídica. 4. ed. Belo Horizonte: Del Rey, 2010.

HABERMAS, Jürgen. Teoria do agir comunicativo I. 2. ed. São Paulo: WMF Martins Fontes, 2012. 
Personalidade Acadêmica Homenageada:

Augustus B. Cochran III (Agnes Scott College)

LEVINAS, Emmanuel. Totalidade e Infinito: ensaio sobre a exterioridade. 3. ed. Tradução de José Pinto Ribeiro. Lisboa: Edições 70, 2011.

LIMA, Beá; OLIVEIRA, Joana; BETIM, Felipe. Morte, ameaças e intimidação: o discurso de Bolsonaro inflama radicais. El País. 11 out. 2018. Disponível em: http://brasil.elpais.com/brasil/2018/10/09/politica/1539112288_960840.html. Acesso em: 30 abr. 2019.

POPPER, Karl. Sociedade aberta e seus inimigos I. Tradução de Milton Amado. Lisboa: Edições 70, 2013.

WITKER, Jorge. Como elaborar uma tesis en derecho: pautas metodológicas y técnicas para el estudiante o investigador del derecho. Madrid: Civitas, 1985. 